\author{
고성능 하이브리드 섬유 보강 콘크리트의 휨 및 유동 특성 \\ 박춘근 ${ }^{1)} \cdot$ 노명현 $^{2)} \cdot$ 박대효 ${ }^{2) *}$ \\ 1) 한국생산기술연구원 ${ }^{2)}$ 한양대학교 토목공학과 \\ (2004년 12월 15일 원고접수, 2005년 7월 28일 심사완료)
}

\title{
Flexural and Workable Properties of High Performance Hybrid Fiber Reinforced Concrete
}

\author{
Choon-Keun Park ${ }^{1)}$, Myung-Hyun Noh ${ }^{2)}$, and Tae-Hyo Park ${ }^{2) *}$ \\ ${ }^{1)}$ KITECH, Cheonan, 330-825, Korea \\ ${ }^{2)}$ Dept. of Civil Engineering, Hanyang University, Seoul, 133-791, Korea
}

(Received December 15, 2004, Accepted July 28, 2005)

\begin{abstract}
In the present work, modulus of rupture (MOR), flexural toughness properties ( $\mathrm{I}_{30}$ and $\mathrm{W}_{2,0}$ ) and workability (slump) of high performance hybrid fiber reinforced concrete (HPHFRC) mixed with micro-fiber (carbon fiber) and macro-fiber (steel fiber), and replaced with a fine mineral admixture such as silica fume (SF) are characterized through the analysis of variance (ANOVA). Data of MOR, $\mathrm{I}_{30}$ (or $\mathrm{W}_{2.0}$ ) and slump are used as the characteristic values to estimate flexural performance and workable property of HPHFRC. Specially, an experimental design was planned according to the fractional orthogoanl array method to reduce experimental number of times. The experimental results show that steel fiber is a considerable significant factor in MOR and $I 30$ ( $W_{2.0}$ ). Based on the significance of experimental factors about each characteristic factors, the following evaluation can be used: Experiment factors which reduce slump most remarkably are carbon fiber, steel fiber, silica fume order.; Those that improve MOR most significantly are silica fume ( $\fallingdotseq$ carbon fiber), steel fiber order; Those that increase flexural toughness most distinctly are silica fume, carbon fiber, steel fiber order. It is obtained that the combination of steel fiber $1.0 \%$, carbon fiber $0.25 \%$ and silica fume $5.0 \%$ is the experimental condition that improve MOR and flexural toughness excellently with workability ensured within the experiment.
\end{abstract}

Keywords : hybrid fiber reinforced concrete, macro/micro fiber, workability, MOR, flexural toughness

\section{1. 서 론}

콘크리트는 내구성 및 경제성이 우수하여 널리 사용되 는 구조 재료 중에 하나이지만 상대적으로 낮은 파괴계수 (modulus of rupture, MOR)와 취약한 관열 저항성, 취성 적 파괴 거동 등의 단점을 지니고 있어 그 사용 범위에 많은 제약이 따른다. 이러한 콘크리트의 단점을 보완하기 위하여 보강재로서 콘크리트 매트릭스 속에 임의로 분산 시킨 단섬유는 매트릭스 내부의 공극과 결함에서 생성되 는 균열의 진전과 합체를 억제함으로써 불안정한 균열 진 전 조건들을 개선하고 앞서 언급한 매트릭스의 단점들을 보완해준다. 그러나 콘크리트는 매트릭스 및 매트릭스와 골재의 경계면 내부에 수 미크론에서 수 밀리미터에 이르

* Corresponding author

E-mail : cepark@hanyang.ac.kr

(C) 2005 by Korea Concrete Institute
는 다양한 크기의 공극 및 결함이 분포하고 있으며 특히, 양생 과정 중의 수축 및 팽창 작용은 미세균열을 생성 및 진전시켜 재하 단계에 따라 수 밀리미터에 이르는 매우 큰 균열로 확대시키기 때문에 한 종류의 크기만을 갖는 단일 섬유 형태로는 일정 수준이상의 섬유 보강 효과를 기대하기가 곤란하다 ${ }^{122}$.

최근에 이러한 단일 섬유 형태의 한계를 극복하기 위한 방안으로 양생 단계에서 발생되는 미세균열 뿐만 아니라 재 하 과정에서 발생되는 다양한 크기의 균열들을 동시에 제어 하기 위하여 다양한 종류와 크기의 섬유를 조합한 새로운 고성능 하이브리드 섬유보강 콘크리트(high performance hybrid fiber reinforced concrete, HPHFRC)에 대한 연구 가 할발히 진행되고 있으며, 섬유를 조합한 하이브리드 시 스템이 단일 시스템보다 더욱 우수한 효과가 있음이 실험 적으로 입증되고 있다. 낮은 섬유 혼입률 $\left(\mathrm{V}_{\mathrm{f}}=0.5 \%\right)$ 에서 하이브리드 섬유 보강 콘크리트의 역학적 특성에 대한 연 
구에서는 강섬유와 탄소 및 폴리프로필렌 섬유를 단일 및 하이브리드 시스템으로 콘크리트에 보강할 경우 강섬유와 기타 섬유를 하이브리드로 보강한 경우가 단일 시스템보 다 우수한 보강 효과가 나타나고, 세 종류의 하이브리드 시스템 중에서도 유사한 고탄성계수를 갖는 강섬유와 탄 소섬유를 조합한 경우가 시너지 작용이 극대화되고 높은 강도와 휨인성이 발현됨을 보였다 ${ }^{3}$. 높은 섬유 혼입률로 마이크로 섬유만을 혼입한 시멘트 복합재에 대한 연구에 서는 강섬유의 경우가 탄소섬유나 유리섬유에 비해 향상 된 $\mathrm{MOR}$ 을, 탄소섬유와 유리섬유는 강섬유보다 우수한 파 괴인성을 갖는 것으로 나타났고, 강섬유와 탄소섬유를 하 이브리드 형태로 보강할 경우에는 각 섬유의 개별 특성인 고강도 및 고인성 특성이 동시에 발현된다고 보고되고 있 다). 또한 마이크로 섬유인 폴리프로필렌 섬유와 매크로 섬유인 강섬유를 조합한 하이브리드 섬유 보강 콘크리트 의 역학적 및 파괴 특성에 관한 연구에서는 두 종류의 섬 유를 보강할 경우 각 섬유의 특성이 고루 반영되어 우수한 강도증진을 갖는 최적조합이 존재함을 보여주었으며 마이 크로 섬유와 매크로 섬유의 인성 특성은 서로 다른 균열 폭에서 효과가 있음을 보였고 두 섬유를 조합할 경우 더욱 뛰어난 파괴 인성이 발현됨이 실험적으로 입증되었단)

이러한 연구실적은 앞으로 섬유보강 콘크리트도 사용 목적과 성격에 맞게 섬유의 종류와 크기를 하이브리드 형 태로 조합할 경우 성능의 극대화가 가능함을 확인해 준 것이다. 그러나 기존의 HPHFRC 연구는 섬유를 하이브리 드 형태로 혼입할 경우 단일 섬유 보강 콘크리트에 비해 강도 및 인성의 증진에 효과적임을 보여주긴 하였지만, 강 도 및 인성이 우수하게 발현되는 섬유조합에 대한 연구와 실제 적용 가능성과 관련이 깊은 유동성에 대해서는 관심 을 소홀이 해왔다.

따라서 본 HPHFRC 연구에서는 실제 현장 적용성에 가 장 중요한 특성으로 고려되는 유동성에 초점을 맞추기 위 해 섬유들의 혼입 및 조합에 따른 섬유 뭉침(fiber balling)에 의한 슬럼프 저하를 고려한다. 또한 미세구조 관점에서 매트릭스와 섬유계면의 부착 특성을 효과적으로 증진시키기 위하여 실리카품을 비율별로 충전한 고밀도 $\mathrm{DSP}^{\text {(5) }}$ (densified with small particles) 시멘트계 재료를 구 성하고, 여기에 다시 강, 탄소 두 가지 섬유를 직교실험원 리에 따라 매트릭스에 보강하여 우수한 $\mathrm{MOR}$ 과 인성을 유도하도록 한다. 본 연구는 일정 수준의 유동성을 갖춘 $\mathrm{HPHFRC}$ 를 유도함과 동시에 우수한 MOR과 에너지 흡수 능력을 갖춘 $\mathrm{HPHFRC}$ 의 배합비 도출을 위해 실리카품 치환비율과 섬유들의 조합비율을 결정하기 위함이다.

\section{HPHFRC 시스템 특성}

$\mathrm{HPHFRC}$ 시스템은 각 섬유의 개별 특성이 효과적으로
발현되어 시너지 보강 효과가 나타나는 최적 섬유조합비 율이 존재한다는 전제를 두고 있다. HPHFRC 시스템에서 는 다양한 크기의 균열들이 효과적으로 제어되도록 서로 다른 크기의 섬유들이 적절하게 조합되어 서로 다른 규모 의 균열들을 제어하는 특성이 있다. 즉, 미크론 단위의 직 경을 갖는 마이크로 섬유(탄소섬유 등)는 미세균열들의 생성과 진전을 호과적으로 억제하며 이를 통해 매트릭스 의 자체의 높은 MOR을 유도한다. 그 이유는 매트릭스 내 의 인장파괴가 미세균열에서 거시균열로의 점진적인 합체 에 따른 미세파괴 수준에서 시작되고, 마이크로 섬유들이 매트릭스 내부에서 이러한 미세균열들의 성장과 진전을 효과적으로 억제해주기 때문이다.8). 매트릭스가 강화 (MOR 증진)되기 위해서는 허용되는 결함의 크기를 임계 결함(critical flaw) 이하로 낮출 필요가 있으며 그 크기를 줄이기 위하여 보강되는 섬유들 사이의 간격은 좁혀져야 한다. 이것은 미세하고 짧게 분리된 수 미크론 단위의 마 이크로 섬유들을 사용할 때 가능하게 된다. 가령 탄소섬 유와 유리섬유와 같은 미크론 단위의 마이크로 섬유들은 매트릭스 내의 균열의 핵인 공극에서 발생된 미세균열들 이 임계 결함의 크기에 도달하기 전에 미세균열들 사이의 교량 역할을 하고 균열들을 편향시켜 합체되는 것을 방해 함으로써 균열 폭의 성장을 억제하고 균열 진전을 효과적 으로 제어하게 된다. 한편, $\mathrm{HPHFRC}$ 시스템에서 밀리미터 단위의 직경을 갖는 매크로 섬유(강섬유 등)는 미세균열 의 진전과 합체로 야기된 주균열을 효과적으로 억제하여 매트릭스의 인성을 현저하게 증진시키는 역할을 한다. 이 때 매크로 섬유는 주로 뽑힘작용(pull-out)이라는 인성 메 커니즘을 통해 상대적으로 높은 파괴인성 값을 갖게 되고 콘크리트의 취성 거동을 연성거동으로 유도하게 된다 ${ }^{9-11)}$.

\section{3. 실험 개요}

\section{1 일부실시 직교 배열에 의한 실험 설계}

본 연구에서는 섬유의 개별적 성능과 실리카품의 재료 적 특성이 최대한 발현되도록 하는 하이브리드 섬유의 혼 입비율과 실리카품 치환율의 조합 범위를 구성하기 위해 직교 실험 원리가 이용되었다. 두 종류의 섬유(강섬유, 탄 소섬유)의 혼입율과 실리카품의 치환율을 $\mathrm{HPHFRC}$ 를 평 가하기 위한 특성인자(slump, MOR, flexural toughness)에 영향을 주는 실험 인자로 하였고, 각 섬유들의 혼입율과 실리카품의 첨가율을 동일하게 세 개의 수준으로 택하여 실험회수를 최소로 하는 일부실시 직교배열(fractional orthogonal array) 방법을 통해 실험이 계획되었다. 본 연 구에 사용된 Table 1의 실험 인자 및 수준으로 만일 1회 1 인자 변화 실험으로 설계할 경우 본 실험은 $3^{3}=27$ 회의 실험 회수가 요구된다. 하지만 일부실시 직교배열에 따르 
면 27회의 실험은 단지 9회로 크게 감소시킬 수 있으며 각각 3개의 실험 인자 및 수준을 모두 평가할 수 있는 장 점을 지니게 된다. 또한 각 인자들의 배열을 살펴보면 수 준들이 동일하게 발생되도록 균형이 잡혀있기 때문에 인 자 하나의 효과를 구할 때 나머지 인자의 영향에 대하여 차우침이 없고, 각 인자들의 평균 효과를 다른 모든 인자 들의 수준이 변하는 동안 결정할 수 있게 된다(직교화의 원리(principle of orthogonality) $)^{12}$.

본 연구에서는 채택된 3 개의 실험 인자들 사이에는 교 호작용이 없다고 가정되었고 강섬유, 탄소섬유, 실리카품 의 주효과만 고려된 경우의 3 인자 3 수준 직교배열 $\mathrm{OA}_{9}\left(3^{3}\right)$ 이 Table 2에 나타나 있다. 이를 통해서 각 섬유 들의 조합 비율과 실리카픔의 치환비율이 결정되었다. Table 2에서 보이는 바와 같이 각각의 열에서 각 인자의 수준은 정확하게 세 번씩 나타나고 각 인자의 수준은 다 른 인자의 각 수준과 정확하게 한 번씩 만난다.

\section{2 사용 재료}

시멘트는 국내 $\mathrm{S}$ 사의 1 종 보통 포틀랜드시멘트(평균 입 경: $18.07 \mathrm{em}$ )가 사용되었고 밀실한 매트릭스 구조를 유도 하기 위해 미세 고로슬래그(분말도: $6,000 \mathrm{~cm}^{2} / \mathrm{g}$, 평균 입 경: $8.07 \mu \mathrm{m})$ 가 결합재 중량비로 $20 \%$ 치환되었다. 또한 섬 유 및 골재 계면의 부착 특성을 개선하고 더욱 치밀한 매 트릭스를 구성하기 위해 시멘트 입자 크기의 약 $1 / 180$ 인 $0.1 \mu \mathrm{m}$ 의 평균입경을 갖는 실리카품이 결합재 중량비로 0 $\%, 2.5 \%, 5 \%$ 씩 비율별로 치환되어 사용되었다. 본 연구 에 사용된 시멘트, 미세고로슬래그, 실리카품의 물리·화 학적 특성이 Table 3에 제시되어 있다. 매트릭스 취성 특 성 개선을 위해 강섬유와 탄소섬유가 사용되었고, 사용된 섬유의 특성이 Table 4에 나타나 있다. 탄소섬유의 경우는 선진 각국에서가격이 저렴하여 PAN 탄소섬유를 대체하여 주로 사용되고 있는 pitch계 탄소섬유가 사용되었다. 사용 된 pitch계 탄소섬유는 PAN 탄소섬유에 비해 인장강도 및 탄성계수는 낮은 값을 보이지만 직경이 $18 \mu \mathrm{m}$ 로서 본 연구 의 HPHFRC 시스템의 마이크로 섬유의 특성을 잘 반영한 다. 강섬유의 경우는 길이가 $30 \mathrm{~mm}$, 직경이 $0.5 \mathrm{~mm}$ 로서 매 크로 섬유의 특성을 잘 반영하고 있다. 또한 실리카퓸과 섬 유들이 매트릭스 내에 일정하게 분산되고 혼합 가능한 배 합범위가 유도되도록 국내 $\mathrm{K}$ 사의 액상 폴리카르본산계 $(\mathrm{PC}$, $40 \%$ solids) 고성능 감수제가 사용되었다.

\section{3 배합 및 양생}

HPHFRC 배합에 사용된 물-결합재 비 $(\mathrm{w} / \mathrm{b}, \mathrm{b}=\mathrm{cement+}$ $\mathrm{BFS}+\mathrm{SF})$ 는 0.26 로 일정하게 고정되었고, 유동성 확보를 위해 최대치수 $\left(\mathrm{G}_{\max }\right)$ 가 $13 \mathrm{~mm}$ 인 굵은 골재가 사용되었다. 결합재, 잔골재, 굵은골재는 각각 $654,678,805 \mathrm{~kg} / \mathrm{cm}^{3}$ 로
Table 1 Experimental factors and levels

\begin{tabular}{|c|c|c|c|}
\hline Factor & Level 1 & Level 2 & Level 3 \\
\hline A: steel fiber ${ }^{a}$ & $0 \%$ & $0.5 \%$ & $1.0 \%$ \\
\hline B: Carbon fiber ${ }^{a}$ & $0 \%$ & $0.25 \%$ & $0.5 \%$ \\
\hline C: Silica fume ${ }^{b}$ & $0 \%$ & $2.5 \%$ & $5.0 \%$ \\
\hline
\end{tabular}

Table $2 \mathrm{OA}_{9}\left(3^{3}\right)$ Orthogonal array for three factors and levels

\begin{tabular}{c|c|c|c|c}
\hline Exp. No. & Factor A & Factor B & Error & Factor C \\
\hline \hline 1 & 1 & 1 & 1 & 1 \\
\hline 2 & 1 & 2 & 2 & 2 \\
\hline 3 & 1 & 3 & 3 & 3 \\
\hline 4 & 2 & 1 & 2 & 3 \\
\hline 5 & 2 & 2 & 3 & 1 \\
\hline 6 & 2 & 3 & 1 & 2 \\
\hline 7 & 3 & 1 & 3 & 2 \\
\hline 8 & 3 & 2 & 1 & 3 \\
\hline 9 & 3 & 3 & 2 & 1 \\
\hline
\end{tabular}

Table 3 Chemical and physical properties of used materials (wt. \%)

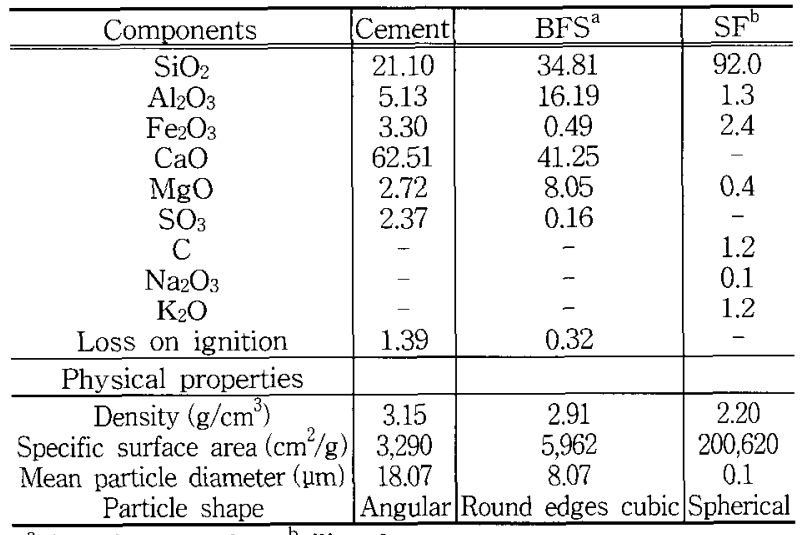

ablast furnace slag, ${ }^{b}$ silica fume

Table 4 Physical properties of fibers

\begin{tabular}{|c|c|c|c|c|c|c|c|}
\hline \multirow{2}{*}{$\begin{array}{l}\text { Fiber } \\
\text { type }\end{array}$} & \multicolumn{3}{|c|}{ Geometry } & \multirow{2}{*}{$\begin{array}{l}\text { Specific } \\
\text { gravity }\end{array}$} & \multirow{2}{*}{$\begin{array}{c}\text { Tensile } \\
\text { strength }\end{array}$} & \multirow{2}{*}{$\begin{array}{c}\text { Modulus } \\
\text { of } \\
\text { elasticity }\end{array}$} & \multirow{2}{*}{$\begin{array}{c}\text { Elongation } \\
\text { at break }\end{array}$} \\
\hline & Length & Diam & $\begin{array}{l}\text { Aspec } \\
\text { ratio }\end{array}$ & & & & \\
\hline & & 0 & 60 & & & $\mathrm{~Pa}$ & \\
\hline $\begin{array}{l}\text { arbon } \\
\text { fiber }\end{array}$ & $\left\{\begin{array}{l}6 \mathrm{~m} \\
\text { (ave }\end{array}\right.$ & $18 \mu \mathrm{m}$ & 35 & $\boldsymbol{J}$ & $590 \mathrm{MPa}$ & $30 \mathrm{GPa}$ & \\
\hline
\end{tabular}

배합되었고, 혼합이 가능하도록 2.0\%(wt.\% of the binder) 의 고성능 감수제가 첨가되었다. Table 2 의 직교배열표에 따라 강섬유, 탄소섬유, 실리카품이 혼합된 아홉 개의 $\mathrm{HPHFRC}$ 배합이 Table 5와 같은 비율로 구성되었다. 각 배합별로 세 개씩 총 27 개의 시편이 $100 \mathrm{~mm} \times 100 \mathrm{~mm} \times$ $350 \mathrm{~mm}$ 의 크기로 성형되었고, 성형된 시편은 항온항습장 치 $\left(20 \pm 3{ }^{\circ} \mathrm{C}, 98 \% \mathrm{RH}\right)$ 에 응결을 위해 보관된 후탈형하여 강도 측정일(재령 28 일)까지 $20{ }^{\circ} \mathrm{C}$ 로 습윤양생되었다. 
Table 5 Mix proportions of HPHFRC

\begin{tabular}{|c|c|c|c|c|}
\hline \multirow[b]{2}{*}{ Exp. no. } & \multicolumn{2}{|c|}{ Factor } & \multirow[b]{2}{*}{$\begin{array}{c}\text { Silica fume } \\
\text { wt.\% (C) }\end{array}$} & \multirow{2}{*}{$\begin{array}{l}\text { Experiment } \\
\text { al condition }\end{array}$} \\
\hline & $\begin{array}{l}\text { Steel fiber } \\
\text { vol. } \%,(\mathrm{~A})\end{array}$ & $\begin{array}{c}\text { Carbon fiber } \\
\text { vol. } \%,(\mathrm{~B})\end{array}$ & & \\
\hline 1(control) & $0(1)$ & $0(1)$ & $0(1)$ & $\mathrm{A}_{1} \mathrm{~B}_{1} \mathrm{C}_{1}$ \\
\hline 2 & $0(1)$ & $0.25(2)$ & $2.5(2)$ & $\mathrm{A}_{1} \mathrm{~B}_{2} \mathrm{C}_{2}$ \\
\hline 3 & $0(1)$ & $0.5(3)$ & $5.0(3)$ & $\mathrm{A}_{1} \mathrm{~B}_{3} \mathrm{C}_{3}$ \\
\hline 4 & $0.5(2)$ & $0(1)$ & $5.0(3)$ & $\mathrm{A}_{2} \mathrm{~B}_{1} \mathrm{C}_{3}$ \\
\hline 5 & $0.5(2)$ & $0.25(2)$ & $0(1)$ & $\mathrm{A}_{2} \mathrm{~B}_{2} \mathrm{C}_{1}$ \\
\hline 6 & $0.5(2)$ & $0.5(3)$ & $2.5(2)$ & $\mathrm{A}_{2} \mathrm{~B}_{3} \mathrm{C}_{2}$ \\
\hline 7 & $1.0(3)$ & $0(1)$ & $2.5(2)$ & $\mathrm{A}_{3} \mathrm{~B}_{1} \mathrm{C}_{2}$ \\
\hline 8 & $1.0(3)$ & $0.25(2)$ & $5.0(3)$ & $\mathrm{A}_{3} \mathrm{~B}_{2} \mathrm{C}_{3}$ \\
\hline 9 & $1.0(3)$ & $0.5(3)$ & $0(1)$ & $\mathrm{A}_{3} \mathrm{~B}_{3} \mathrm{C}_{1}$ \\
\hline
\end{tabular}

\section{4 시편의 평가 방법}

\subsection{1 시험 방법}

$\mathrm{HPHFRC}$ 의 특성평가 인자로 고려된 슬럼프, $\mathrm{MOR}$ 과 휨 인성을 측정하기 위해서 슬럼프 시험의 경우 KS F 2402 에 준하여 실시되었고, 휨인성과 MOR은 ASTM C 1018 에 준하여 실시된 3 등분점 재하 시험을 통해 얻어진 하중 처짐곡선을 분석하여 얻어졌으며, 안정적인 하중과 처짐 응답 관계를 얻기 위해 시편 지간의 $1 / 1,500$ 인 $0.2 \mathrm{~mm} / \mathrm{min}$ 속도의 변위제어방식으로 가력되었다. 휨 시험을 위하여 SMADZU사의 100 톤 용량의 만능 시험기가 사용되었으 며, 외부기기와 지점부의 이상 변형으로 발생되는 외부처 짐을 배제하기 위하여 지간 중앙에 $50 \mathrm{~mm}$ 용량의 LVDT 를 설치한 요크(yoke)방식을 채택하여 순수처짐이 측정되 었다. 시편이 설치된 측정 장비의 모습은 Fig. 1 과 같다.

\subsection{2 특성 인자 평가 및 데이터 분석}

$\mathrm{HPHFRC}$ 의 특성 인자 평가를 위해 슬럼프 시험을 통해 얻어진 각 배합의 슬럼프 값과 하중 처짐 응답 관계를 분 석하여 얻어진 각 시편의 파괴계수(MOR, modulus of rupture), 휨인성지수( $\mathrm{I}_{30}$, toughness index), $\delta=2 \mathrm{~mm}$ 까지 흡수에너지( $W_{2.0}$, absorbed energy)의 시험 결과로부터 각 실험 인자에 대한 변동값을 구하고 분산분석 ${ }^{12)}$ (ANOVA, analysis of variance)이 실시되었다. 분산분석을 위한 데 이터의 구조식은 다음과 같이 가정된다.

$$
x_{i j k}=\mu+a_{i}+b_{j}+c_{k}+e_{i j k}
$$

여기서, $\mu$ 는 측정된 각 특성인자들의 모평균이고, $a_{i}, b_{j}, c_{k}$ 는 각각 $A_{i}, B_{j}, C_{k}$ 수준이 주는 효과이며 $\sum_{i} a_{i}=\sum_{j} b_{j}=$ $\sum_{k} c_{k}=0$ 의 관계를 만족한다. $i, j, k(=0,1,2)$ 는 수준수이며, $e_{i j k} \sim \mathrm{N}\left(0, \sigma_{E}^{2}\right)$ 이고 서로 독립이며 측정시 발생되는 오차 를 의미한다.

분산분석이 수행된 후 각 실험인자에 대해서 $\mathrm{HPHFRC}$ 의 각 특성치들이 가장 우수한 배합 조건이 도출되었고 배합 조건별로 모평균의 점추정이 수행되었으며 가장 우 수한 배합에 대해서는 구간추정이 수행되었다. 이때 실험

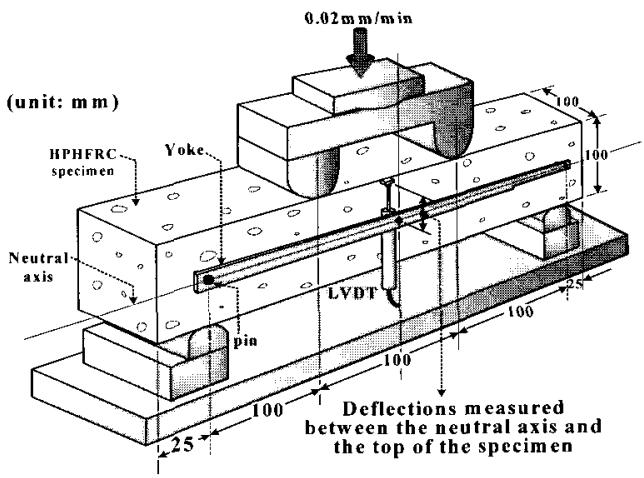

Fig. 1 Test set-up

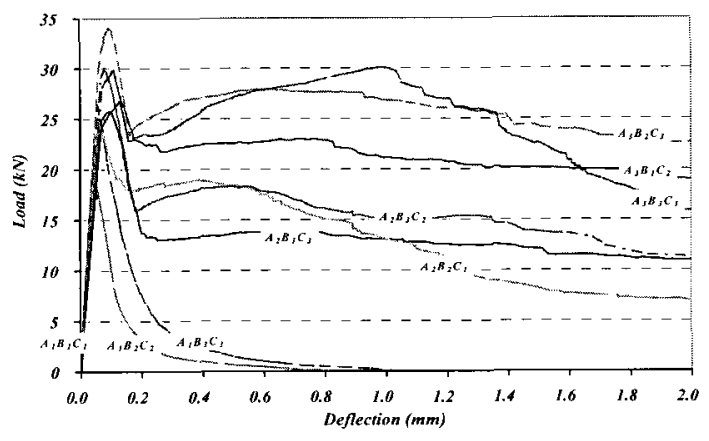

Fig. 2 Load vs. deflection response curves for HPHFRC specimens

데이터의 수가 적어 정규분포를 따르지 않음을 고려하여 실험 데이터는 자유도(degree of freedom, $\phi$ )의 $\mathrm{t}$-분포를 이룬다고 가정하였다. 따라서 점추정치(point estimate)는 $\mathrm{t}$-통계량을 의미하고 구간추정(interval estimation)은 95 $\%$ 신뢰구간에서 수행되었다.

\section{4. 결과 및 분석}

HPHFRC의 시편에 대해서 무작위로 실시된 휨 시험 결 과 기준시편 $\left(\mathrm{A}_{1} \mathrm{~B}_{1} \mathrm{C}_{1}\right)$ 을 제외한 모든 시편에서 휨 거동이 연성으로 유도되는 것으로 나타난다(Fig. 2). 총 27개의 휨 시험 결과로부터 각 실험 인자의 변동에 대한 분산분석을 통해 얻어진 각 특성인자들(슬럼프, $\mathrm{MOR}$, 휨인성)의 실험 조건별 통계적 점추정치와 증감률이 Table 6에 제시된다.

\subsection{HPHFRC의 특성인자 평가}

\subsection{1 슬럼프 평가}

강섬유, 탄소섬유, 실리카품은 모두 슬럼프에 유의한 영 향을 미치는 인자로 나타난다. 특히 Table 6에 보이는 것 처럼 탄소섬유가 혼입되면 배합에 급격한 유동성 감소가 초래된다. 탄소섬유 없이 강섬유만 단독으로 $1.0 \%$ 로 혼입 된 $\mathrm{A}_{3} \mathrm{~B}_{1} \mathrm{C}_{2}$ 배합과 강섬유 $0.5 \%$ 에 탄소섬유가 각각 $0.25 \%$, $0.5 \%$ 씩 혼입된 $\mathrm{A}_{2} \mathrm{~B}_{2} \mathrm{C}_{1}, \mathrm{~A}_{2} \mathrm{~B}_{3} \mathrm{C}_{2}$ 하이브리드 배합을 서로 비교해 보면 총 섬유 혼입율이 오히려 작거나 같은 하이 
브리드 배합의 슬럼프 값이 크게 감소된다. 이는 강섬유 가 탄소섬유와 함께 혼합될 경우 급격한 유동성 손실 가 능성이 있음을 암시한다. 탄소섬유는 평균 직경이 $18 \mu \mathrm{m}$ 정도인 약 10,000 여개의 단섬유가 모인 토우(tow)로 구성 되어 있기 때문에 높은 비표면적을 지니고 비빔과정에서 매트릭스 내로 일정하고 고르게 분산되기가 쉽지 않다단. 이러한 이유로 탄소섬유는 슬럼프 저하에 가장 유의한 인 자 $\left(\mathrm{F}_{\mathrm{B}}=146.1\right)$ 로 분석된다. 또한 탄소섬유의 흔입과 혼입률 증가에 따라 초래된 유동성 손실은 탄소 섬유의 고른 분 산효과를 저하시키고 오히려 마이크로 섬유의 고유 특성 인 마이크로 균열제어 능력을 둔화시켜 주균열 발생 이전 의 강도 증진 효과를 뚜렷하게 나타내지 못한다. 그러나 탄소섬유와 실리카퓸이 혼합될 경우 직경이 $18 \mu \mathrm{m}$ 인 탄소 섬유들 사이에 $0.1 \mu \mathrm{m}$ 의 미세한 실리카품 입자가 고르게 침투되어 볼 베어링 작용을 함으로써 간접적인 섬유 분산 효과가 나타난다. Table 6에 보이는 것처럼 실리카품이 전혀 치환되지 않은 배합보다 오히려 $2.5 \%, 5.0 \%$ 씩 치환 된 경우 평균적으로 슬럼프가 덜 감소된다. 따라서 강섬 유와 탄소섬유를 조합할 경우 실리카품을 혼합하여 유동 성 격감현상이 제어되어야 한다.

\subsection{2 $\mathrm{MOR}$ 평가}

강섬유는 $\mathrm{MOR}$ 증진에 가장 우수한 효과를 보이며 실 리카퓸과 탄소섬유인자는 서로 유사한 $\mathrm{MOR}$ 증진 효과를 나타내지만 강섬유 인자보다는 다소 낮은 효과를 갖는 것 으로 평가된다(Table 7). 이 결과는 HPHFRC 시스템 구 성 시 예상했던 바와 같이 탄소섬유와 같은 마이크로 섬 유의 경우 주균열 발생 이전단계에서 마이크로 균열을 제 어하면서 $\mathrm{MOR}$ 증진측면에 관여하고 강섬유와 같은 매크 로 섬유의 경우 주균열 발생 이후 단계에서 매크로 균열 을 제어하면서 인성증진측면에 관여할 것이라는 예측과 일치되지 않는다. 그 이유는 강섬유의 경우 탄소섬유에 비해서 섬유 혼입률이 높을 뿐만 아니라 탄소섬유와 시멘 트페이스트에 비해서 높은 인장강도와 탄성계수를 지니고 있기 때문에 매트릭스 내에 균질하게 분포될 경우 매트릭 스의 전체적인 성능을 개선시켜 하중 전달 능력을 항상시
킬 수 있기 때문이다. 이러한 효과로 강섬유는 MOR 증진 에 일정 수준 기여하게 된다.

탄소섬유의 경우는 MOR 증진 효과가 강섬유에 비해 다소 낮게 평가되는데 그 원인은 다음과 같이 몇 가지 점에서 고 려된다. 첫째, 앞서 언급된 탄소섬유의 분산효과 저하로 인 해 마이크로 섬유의 고유특성이 제대로 발현되지 못한 점. 둘째, 고탄성 고인장강도 특성이 있는 고가의 PAN 탄소섬 유를 대체하여 사용한 pitch계 탄소섬유가 강섬유에 비해 인 장강도는 유사하지만 탄성계수가 현저하게 낮다는 점. 셋째, 유동성 확보를 위해 높은 비표면적을 지닌 탄소섬유의 혼입 률 $(\leq 0.5 \%)$ 을 강섬유의 흔입률 $(\leq 1.0 \%)$ 보다 상대적으로 낮 게 설정한 점이다. 그 결과 분산분석 시 오히려 매크로 섬유 인 강섬유에 비해 마이크로 섬유인 탄소섬유의 경우의 $\mathrm{MOR}$ 중진효과가 상대적으로 낮게 분석된다(Table 7).

Table 7 ANOVA results

\begin{tabular}{|c|c|c|c|c|}
\hline Factor & $S_{i}^{a}$ & $\Phi_{i}^{b}$ & $V_{i}^{\mathrm{C}}$ & $F_{i}^{\mathrm{d}}$ \\
\hline \multicolumn{5}{|c|}{ Slump } \\
\hline A (steel fiber) & 217.7 & 2 & 108.86 & 17.1 \\
\hline $\mathrm{B}$ (carbon fiber) & $1,858.7$ & 2 & 929.36 & 146.1 \\
\hline $\mathrm{C}$ (silica fume) & 153.5 & 2 & 76.75 & 12.1 \\
\hline $\mathrm{E}$ (error) & 12.7 & 2 & 6.36 & \\
\hline Total & $2,242,6$ & 8 & & \\
\hline \multicolumn{5}{|c|}{$M O R$} \\
\hline $\mathrm{A}$ & 18.2 & 2 & 9.11 & 21.9 \\
\hline B & 7.7 & 2 & 3.83 & 9.2 \\
\hline $\mathrm{C}$ & 8.6 & 2 & 4.28 & 10.3 \\
\hline $\mathrm{E}$ & 0.8 & 2 & 0.42 & \\
\hline Total & 35.3 & 8 & & \\
\hline \multicolumn{5}{|c|}{ Toughness index, $I_{30}$} \\
\hline $\mathrm{A}$ & $2,620.0$ & 2 & $1,309.98$ & 47.6 \\
\hline B & 35.4 & 2 & 17.72 & 0.6 \\
\hline $\mathrm{C}$ & 0.3 & 2 & 0.14 & 0.0 \\
\hline $\mathrm{E}$ & 55.1 & 2 & 27.55 & \\
\hline Total & $2,710.8$ & 8 & & \\
\hline \multicolumn{5}{|c|}{ Absorbed energy, $W_{20}$} \\
\hline A & $9,186.6$ & 2 & $4,593.31$ & 193.2 \\
\hline $\mathrm{B}$ & 135.3 & 2 & 67.64 & 2.8 \\
\hline $\mathrm{C}$ & 27.3 & 2 & 13.63 & 0.6 \\
\hline $\mathrm{E}$ & 47.5 & 2 & 23.77 & \\
\hline Total & $9,396.7$ & 8 & & \\
\hline
\end{tabular}

${ }^{a}$ Sum of squares of $i(=A, B, C$ and $E)$ factor

${ }^{\mathrm{b}}$ Degree of freedom, ${ }^{\mathrm{C}} \mathrm{Mean}$ square

${ }^{d} \mathrm{~F}$ value: ratio of mean square $\left(\mathrm{V}_{\mathrm{i}} / \mathrm{V}_{\mathrm{E}}\right)$

Table 6 Results of statistical point estimation about experimental data

\begin{tabular}{|c|c|c|c|c|c|c|c|}
\hline \multirow{2}{*}{$\begin{array}{c}\text { Experimental } \\
\text { condition }\end{array}$} & \multicolumn{2}{|c|}{ Slump } & \multicolumn{2}{|c|}{ Modulus of rupture } & \multirow{2}{*}{\begin{tabular}{|c|} 
Toughness Index $\left(\mathrm{I}_{30}\right)$ \\
Estimate \\
\end{tabular}} & \multicolumn{2}{|c|}{ Absorbed energy $\left(\mathrm{W}_{2.0}\right)$} \\
\hline & Estimate $(\mathrm{cm})$ & Decrement ${ }^{\mathrm{a}}(\%)$ & Estimate $(\mathrm{MPa})$ & Increment ${ }^{b}(\%)$ & & Estimate $(\mathrm{N} \cdot \mathrm{mm})$ & Increment $^{c}$ (ratio) \\
\hline $\mathrm{A}_{1} \mathrm{~B}_{1} \mathrm{C}_{1}$ & 28.0 & - & 5.5 & - & 1.0 & 0.39 & 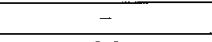 \\
\hline $\mathrm{A}_{1} \mathrm{~B}_{2} \mathrm{C}_{2}$ & 19.7 & -30 & 6.8 & 24 & 5.5 & 2.68 & 6.9 \\
\hline $\mathrm{A}_{1} \mathrm{~B}_{3} \mathrm{C}_{3}$ & 10.9 & -61 & 8.1 & 47 & 4.5 & 6.10 & 15.6 \\
\hline $\mathrm{A}_{2} \mathrm{~B}_{1} \mathrm{C}_{3}$ & 26.4 & -6 & 8.0 & 45 & 18.4 & 26.90 & 69.0 \\
\hline $\mathrm{A}_{2} \mathrm{~B}_{2} \mathrm{C}_{1}$ & 9.6 & -66 & 7.2 & 31 & 21.3 & 28.71 & 73.6 \\
\hline $\mathrm{A}_{2} \mathrm{~B}_{3} \mathrm{C}_{2}$ & 9.8 & -65 & 8.7 & 58 & 20.4 & 30.05 & 77.1 \\
\hline $\mathrm{A}_{3} \mathrm{~B}_{1} \mathrm{C}_{2}$ & 26.9 & -4 & 8.2 & 49 & 26.5 & 43.72 & 112.1 \\
\hline $\mathrm{A}_{3} \mathrm{~B}_{2} \mathrm{C}_{3}$ & 9.7 & -65 & 9.4 & 71 & 29.1 & 49.79 & 127.7 \\
\hline $\mathrm{A}_{3} \mathrm{~B}_{3} \mathrm{C}_{1}$ & 1.4 & -95 & 8.8 & 60 & 28.5 & 48.95 & 125.5 \\
\hline
\end{tabular}


본 연구 결과와는 약간 상이하지만 기존의 연구에서는 매크로 섬유인 강섬유에 비해 마이크로 섬유인 탄소섬유가 마이크로 균열들을 좀더 효과적으로 제어할 수 있기 때문 에 $\mathrm{MOR}$ 증진에 유리한 것으로 보고하고 있다, ${ }^{4}$. 그 이유 는 초기균열 이후 생성되는 수많은 마이크로 균열들의 규 모가 마이크로 섬유의 직경과 유사한 미크론 단위이며 이 러한 마이크로 섬유는 마이크로 균열들을 효과적으로 편향 시키고 진전을 억제할 수 있어 매크로 균열로의 급속한 합 체를 제어해주기 때문이다. 이러한 마이크로 섬유의 마이크 로 균열 제어 작용은 매트릭스의 성능을 개선하고 효과적 으로 MOR을 증진시킨다. 본 연구에서는 $\mathrm{HPHFRC}$ 시스템 을 구성하면서 탄소섬유가 $\mathrm{MOR}$ 증진에 가장 유의할 것이 라는 기존의 연구와 동일한 결과를 예상했지만, 앞서 언급 된 원인에 의해 기대했던 수준의 효과까지는 나타나지 않 았다. 따라서 향후 강섬유 수준의 탄성계수와 인장강도를 갖는 탄소섬유를 동일한 범위의 혼입률로 고르게 분산시킨 $\mathrm{HPHFRC}$ 시스템을 구성하고 탄소섬유가 MOR 증진측면에 서 의도한 유의수준까지 도출될 수 있는지 여부에 대한 연 구의 필요성이 제기된다.

실리카품의 경우는 배합에 치환하여 사용할 경우 높은 포졸란 반응률과 입자 충전 효과로 인해 매트릭스의 치밀 화가 유도되어 매트릭스 성능이 개선되기 때문에 MOR 증 진에 효과적인 것으로 잘 알려져 있다. 실리카품은 치환율 이 증가될수록 시멘트의 수화작용으로 생성되는 포틀랜다 이트 $(\mathrm{CH})$ 와 반응을 하며 미세한 치밀질 수화물인 $\mathrm{CSH}$ 겔 의 생성량을 증가시킨다 ${ }^{14,15)}$. 또한 실리카품은 평균입경이 $0.1 \mu \mathrm{m}$ 로 아주 미세하기 때문에 치환율의 증가에 따라 본 연구의 배합에 사용된 시멘트 입자 $($ 평균입경 $=18.07 \mu \mathrm{m})$ 및 미세 고로슬래그 입자(평균입경 $=8.07 \mu \mathrm{m})$ 와 함께 콘크리트 매트릭스를 고밀도로 충전시키는 물리적인 효과를 발휘한 다. 이로 인해 실리카품 치환율이 증가됨에 따라 시멘트 매 트릭스의 내부 공극의 양이 상당히 감소되고 매트릭스 내 의 균열 발생의 핵이 될 수 있는 고유 결함(inherent flaw) 의 크기가 효과적으로 감소된다고 할 수 있다.

\subsection{3 휨인성 평가}

강섬유는 휨인성 증진 $\left(\mathrm{I}_{30}, \mathrm{~W}_{2.0}\right)$ 에 가장 탁월한 효과를 발휘하는 것으로 나타난다(Table 7). 이처럼 강섬유가 휨 인성에 가장 유의한 영향을 나타내는 이유는 주균열 발생 이후 급격히 진전되는 매크로 균열들이 강섬유에 의해 효 과적으로 제어되기 때문이다. Fig. 2의 하중 처짐 응답곡 선에서 보이는 바와 같이 강섬유의 혼입률이 증가될수록 주균열 발생 이후 균열에 저항하는 흡수 에너지가 증가된 다. 강섬유의 주요 인성 증진 메커니즘은 매트릭스와 섬 유계면의 부착력을 통한 뽑힘(pull-out)작용이며 강섬유의 혼입률의 증가는 균열에 저항할 수 있는 섬유의 유효개소 를 증가시켜 콘크리트의 파괴거동을 연성으로 효과적으로 유도하고 인성을 대폭 증가시킨다.
분산분석 결과 휨인성 특성치에 대한 탄소섬유의 주효 과는 $\mathrm{F}_{\mathrm{B}}=0.6$ 과 $2.6\left(\mathrm{I}_{30}\right.$ 과 $\mathrm{W}_{20 .}$ 의 경우)으로 유의한 결과를 보이지 않는다. 이 결과는 HPHFRC 시스템의 탄소섬유와 같은 마이크로 섬유는 $\mathrm{MOR}$ 증진측면에 관여하고 인성증 진 측면에는 큰 효과가 없을 것이라는 예측과 잘 부합된 다. 그러나 Fig. 2의 휨 처짐 응답 곡선에서 보이는 바와 같이 강섬유 흔입량 $\left(\mathrm{V}_{\mathrm{f}}=1.0 \%\right)$ 이 일정한 하이브리드 섬유 보강 콘크리트 $\left(\mathrm{A}_{3} \mathrm{~B}_{2} \mathrm{C}_{3}, \mathrm{~A}_{3} \mathrm{~B}_{3} \mathrm{C}_{1}\right)$ 와 강섬유 보강 콘크리트 $\left(\mathrm{A}_{3} \mathrm{~B}_{1} \mathrm{C}_{2}\right)$ 를 비교해 보면 실리카 흄의 치환율과는 상관없 이 탄소섬유 혼입률이 중가됨에 따라 최대하중 이후. 처짐 이 증가하는 현상이 다소 나타나는데 이를 통해 탄소섬유 도 주요한 효과는 아니지만 인성증진에 일정수준 효과가 있음이 확인된다. 분산분석 결과 탄소섬유의 주효과가 유 의하지 않으므로 강섬유와 탄소섬유의 교호작용 즉, 시너 지 작용에 의해 인성이 일정 수준 증진된다고 할 수 있다. 본 연구에서는 탄소 및 강섬유의 교호작용 효과가 오차로 무시되고 각 섬유들의 주효과만 분석되었기 때문에 강섬 유와 탄소섬유는 상호효과는 정량적으로 알 수 없다. 따 라서 항후 탄소섬유와 강섬유의 상호 작용에 대한 정량적 인 분석을 위해서는 두 섬유의 교호작용을 고려한 연구의 필요성이 졔기된다.

본 연구에서 실리카품의 치환은 치밀한 매트릭스를 유 도하여 매트릭스 자체의 성능을 개선시키기 때문에 $\mathrm{MOR}$ 을 높이는 효과를 나타내지만, 이러한 매트릭스의 개선이 직접적인 인성증진으로 나타나지는 않는다(Table 7). 즉, 분산분석 결과에서 확인되는 것처럼 횜인성 증진측면에서 실리카품의 주효과는 무시할 수 있다. 그러나 기존의 문 헌 ${ }^{16-19)}$ 에 따르면 실리카품을 치환하여 섬유와 매트릭스의 부착강도가 임계부착강도( $\left.\tau_{c}\right)$ 이하가 되도록 하는 경우, 실 리카품은 포졸란 반응을 통해 매트릭스와 섬유계면의 결 함부에 치밀하고 견고한 계면조직인 $\mathrm{CSH}$ 생성량을 증가 시키기 때문에 섬유의 부착강도를 항상시키고 주균열 발 생이후 섬유의 뽑힘 성능을 개선하여 시편의 파괴거동을 연성으로 유도한다고 보고하고 있다. 하지만 실리카품의 치환율이 매우 높아 임계부착강도 $(\tau)$ 이상의 강도가 발현 되는 경우, 이론적으로 섬유가 지닌 인장강도만큼의 응력 에 견딜 수 있게 되어 매트릭스와의 점진적인 부착파괴가 발생되기도 전에 섬유 자체가 파괴되어 에너지가 급격히 발산되는 취성거동이 나타난다고 보고하고 있다. 본 연구 에서는 실리카품의 치환비율이 비교적 낮기 때문에 Fig. 2 에서 보이는 바와 같이 주균열 이후 섬유 자체가 파괴되 어 에너지가 급격히 발산되는 취성거동은 보이지 않는다. 이상의 분산분석과 문헌고찰로부터 실리카푬은 휨인성 중 진측면에서 주효과는 유의치 않지만 휨인성 증진의 주요인 자인 강섬유와 조합할 경우 부착성능 항상을 통해 간접적 으로 휨인성을 증진시키는 효과가 있음이 확인된다. 그러나 본 연구에서는 이러한 간접적인 상호효과가 오차로 해석되 었기 때문에 향후 휨인성의 증진에 가장 중요한 인자가 되 
는 강섬유와의 실리카품의 교호작용에 의한 부착효율을 좀 더 정량적으로 특성화하기 위한 연구의 필요성이 제기된다.

\section{2 특성인자 평가 및 실험인자별 수준의 평균 기여도}

본 연구의 HPHFRC 시스템 특성인자들(슬럼프 $\mathrm{MOR}$, 휨 인성)은 Table 7의 분산분석결과를 통해 실험인자들(강섬유, 탄소섬유, 실리카품)의 유의도에 따라 다음과 같이 평가된다. (1) 슬럼프 저하요인 (유동성 저해인자): 탄소섬유 》> 강 섬유> 실리카품

(2) MOR (휨강도 증진요인): 강섬유> 실리카퓸 $\fallingdotseq$ 탄소섬유 (3) $\mathrm{I}_{30}$ 및 $\mathrm{W}_{20}$ (휨인성 증진요인): 강섬유 〉 탄소섬유 $>$ 실리카품

또한 실험인자별 수준에 따라 특성평가 인자에 미치는 정도를 평가할 수 있는 평균 기여도는 각 수준과 일치하는 실험조건의 데이터들을 더하고 그 합을 그 수준의 반복수 로 나눔으로써 계산된다. 각 실험 인자의 수준에 따른 슬럼 프, $\mathrm{MOR}, \mathrm{I}_{30}$ 및 $\mathrm{W}_{2.0}$ 의 특성인자에 대한 평균 기여도가 Fig. 3에 나타난다. 강섬유와 탄소섬유의 경우 혼입률 수준 이 증가함에 따라 슬럼프가 감소되는데 특히 탄소섬유는 그러한 감소현상이 두드러진다. 실리카품은 비 치환하는 것 보다 $2.5 \%$ 수준에서 치환하는 것이 유동성측면에 좀더 기 여를 하는 것으로 나타나며 $5.0 \%$ 치환하는 경우 오히려 저하되는 현상이 보인다. MOR의 경우는 강섬유, 탄소섬유, 실리카품 모두 혼입 및 치환율 수준이 증가할수록 기여도 가 향상된다. 실리카퓸과 탄소섬유는 실험수준에 따라 휨인 성 증진에 일정한 경향이 나타나지 않아 수준별 기여효과 가 명확하지 않으며, 강섬유는 혼입률 수준 증가에 따라 휨 인성 증진에 탁월한 기여를 한다. 이상의 실험인자별 수준 의 평균기여도만을 고려해 볼 때 HPHFRC 시스템의 각 특 성인자들이 모두 우수한 배합을 도출하기 위해서는 휨인성 측면에서 강섬유의 혼입률을 최대한 높이고 유동성 측면에서 탄소섬유의 혼입율과 실리카품의 치환율을 조절하여 각 수준 을 결정하는 방법이 가장 타당하다고 할 수 있다.

\section{3 각 특성치가 우수한 조합 도출}

일반적으로 슬럼프는 구조물의 상태, 시공여건 등에 따라 선택되며 보통 $8 \mathrm{~cm}, 12 \mathrm{~cm}$ 가 가장 많이 사용되고 있다. 본 연구에서는 유동성 측면에서 최소 $8 \mathrm{~cm}$ 이상 슬럼프의 확 보를 전제로 하여 나머지 특성치가 우수한 조합을 도출한 다. 실제 수행된 9 개의 실험조건에서 얻어진 각 특성치에 대한 실험 데이터들이 각각 자유도의 $\mathrm{t}$-분포를 이룬다고 가정되었고 신뢰구간 $95 \%$ 에서 구간추정이 수행되었다. 그 결과 실제로 실험을 수행하지 않은 조합을 모두 포함 한 $3^{3}=27$ 개의 실험조건 중에서 유동성이 가장 높은 배합은 기준배합인 $\mathrm{A}_{1} \mathrm{~B}_{1} \mathrm{C}_{1}$ 으로 슬럼프가 $28.0 \pm 3.5 \mathrm{~cm}$ 였으며, $\mathrm{MOR}$ 이 가장 높은 배합은 강섬유 $1.0 \%$, 탄소섬유 $0.25 \%$, 실리카품 $5.0 \%$ 를 혼합한 $\mathrm{A}_{3} \mathrm{~B}_{2} \mathrm{C}_{3}$ 으로 $9.4 \pm 1.4 \mathrm{MPa}$ 로 나 타났고, 휨인성이 가장 좋은 배합은 강섬유 $1.0 \%$, 탄소섬 유 $0.25 \%$, 실리카품 $2.5 \%$ 를 혼합한 $\mathrm{A}_{3} \mathrm{~B}_{2} \mathrm{C}_{2}$ 로 $\mathrm{I}_{30}=29.3 \pm 3.2$ 로 추정되었다. 실제 실험을 수행한 범위 내에서는 강섬유 $1.0 \%$, 탄소섬유 $0.25 \%$, 실리카품이 $5.0 \%$ 로 치환된 $\mathrm{A}_{3} \mathrm{~B}_{2} \mathrm{C}_{3}$ 의 실험조건이 슬럼프 $=9.7 \pm 3.5 \mathrm{~cm}, \mathrm{MOR}=9.4 \pm 1.4$ $\mathrm{MPa}, \mathrm{I}_{30}=29.1 \pm 3.2$ 로 가장 뛰어난 특성치를 나타내었다.

\section{5. 결 론}

본 실험에서는 슬럼프, 휨강도 $(\mathrm{MOR})$, 휨인성지수( $\left.\mathrm{I}_{30}\right)$ 및 흡수에너지 $\left(\mathrm{W}_{2.0}\right)$ 특성인자에 대한 분산분석을 통해 고 성능 하이브리드 섬유보강 콘크리트가 평가되었다.

분산분석 결과 슬럼프 저하요인(유동성 저해인자)으로는 탄소섬유 > 강섬유 > 실리카퓸, 휨강도(MOR) 증진요인 으로는 강섬유 > 실리카품 $\fallingdotseq$ 탄소섬유, 휨인성 $\left(\mathrm{I}_{30}\right.$ or $\mathrm{W}_{2.0}$ ) 증진요인으로는 강섬유 >> 탄소섬유 > 실리카품 크기 순으로 유의한 효과를 나타내었다. 강섬유는 MOR과 $\mathrm{I}_{30}\left(\mathrm{~W}_{2.0}\right)$ 증진에 가장 유의한 인자였으며, 본 실험범위에 서는 탄소섬유와 실리카품은 상대적으로 $\mathrm{MOR}$ 과 $\mathrm{I}_{30}\left(\mathrm{~W}_{20}\right)$ 증진에 미미한 효과를 보였다. 27 개의 모든 실험조건 중에

서 유동성은 기준배합이, $\mathrm{MOR}$ 은 강섬유 $1.0 \%$, 탄소섬

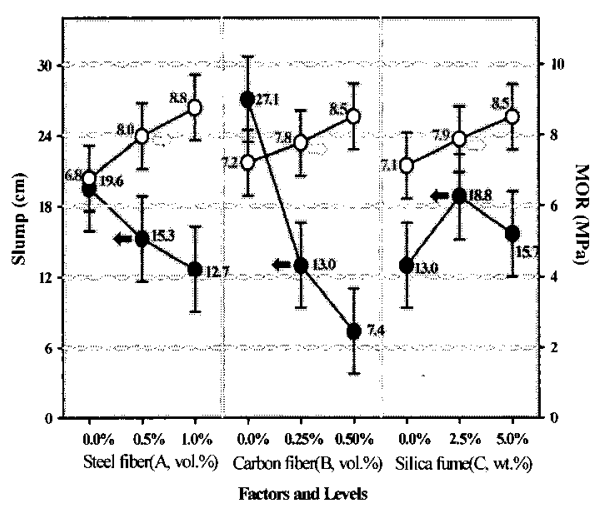

(a) Slump and MOR

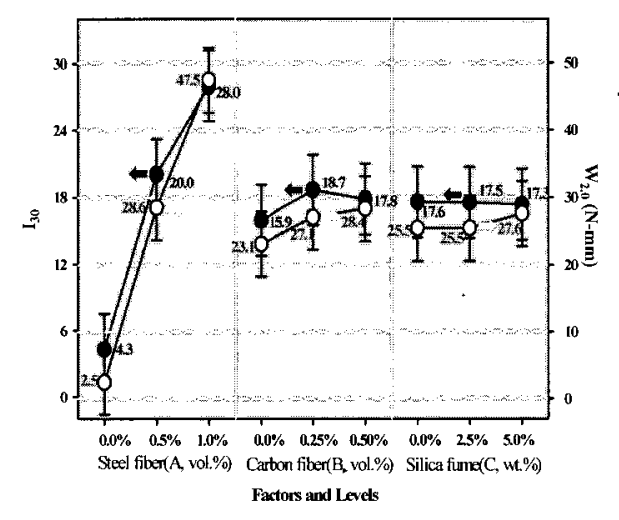

(b) $I_{30}$ and $W_{2.0}$
Fig. 3 Average contribution effect of each experimental factors and levels on characteristic factors
유 $0.25 \%$, 실리카품이 $5.0 \%$ 를 혼합한 조합이, 휨인성은 강섬유 $1.0 \%$, 탄소섬유 0.25 $\%$, 실리카품 $2.5 \%$ 를 혼합한 조합이 가장 높게 추정되었고, 실제 실험을 수행한 범위 내 에서는 강섬유 $1.0 \%$, 탄소섬 유 $0.25 \%$, 실리카품이 $5.0 \%$ 로 치환된 경우가 슬럼프 $=9.7$ $\mathrm{cm}, \mathrm{MOR}=9.4 \mathrm{MPa}, \mathrm{I}_{30}=29.1$ 로 가장 우수한 특성치를 보였다.

본 연구결과 탄소섬유가 $\mathrm{MOR}$ 증진 측면에서 당초 기 
대했던 바와 달리 낮게 평가되었는데, 향후 그 원인들로 분 석된 낮은 탄성계수, 높은 비표면적에 따른 분산저하 문제, 유동성 확보를 위해 불가피 했던 낮은 섬유 혼입율 문제들 을 해결한 연구의 필요성이 제기된다. 또한 실험인자의 주 효과만 분석되어 휨인성 증진 측면에서 오차로 해석된 두 섬유의 시너지 효과와 강섬유와의 실리카품의 상호작용에 따른 부착효율 향상 부분은 추후 각 실험인자의 교호작용 을 고려하여 좀더 정량적으로 분석될 필요가 있다.

\section{감사의 글}

본 연구는 건설교통부의 건설교통기술혁신사업(02 산학 연A03-01)의 일환으로 수행되었으며, 이에 감사드립니다.

\section{참고문헌}

1. Qian, C. X and Stroeven, P., "Fracture Properties of Concrete Reinforced with Steel-Polypropylene Hybrid Fibres", Cement and Concrete Composites, Vol.22, No.5, 2000, pp.343 351.

2. Sun, W., Chen, H, Luo, X and Qian, H, "The Effect of Hybrid Fibers and Expansive Agent on the Shrinkage and Permeability of High-Performance Concrete", Cement and Concrete Research, Vol.31, No.4, 2001, pp.595 601.

3. Yao, W., Li, J. and Wu, K, "Mechanical Properties of Hybrid Fiber-Reinforced Concrete at Low Fiber Volume Fraction", Cement and Concrete Research, Vol.33, No.1, 2003, pp.27 -30.

4. Banthia, N. and Sheng, J., "Fracture Toughness of Micro-Fiber Reinforced Cement Composites", Cement and Concrete Composites, Vol.18, No.4, 1996, pp.251 269.

5. Qian, C. X and Stroeven, P., "Development of Hybrid Polypropylene-Steel Fibre-Reinforced Concrete", Cement and Concrete Research Vol.30, No.1, 2000, pp.63 69.

6. Jenning, H. M., "Advanced Cement-Based Matrices Composite", Proceedings of the International Workshop 'High Performance Fiber reinforced cement composites', RIEM, ACI, Stuttgart University and the University of Michigan, Mainz, Germany, 1991, No.1, pp.3 17.

7. Banthia, N. and Sheng, J., "Micro-Reinforced Cementitious Materials", Materials Research Society
Symposium Proceedings, Material Research Society, Boston, USA, Vol.211, No.1, 1991, pp.25 32.

8. Bayasi, Z. and Peterson, G., "Use of Small-Diameter Polypropylene Fibres in Cement-Based Materials", International Conference on Recent Developments in Fiber Reirforced Cement and Concrete, University of Wales College of Cardiff, UK, 1989, pp.200 208.

9. Li, V. C. and Maalej, M, "Toughening in Cement Based Composites. Part I: Cement, Mortar, and Concrete", Cement and Concrete Composites, Vol.18, No.4, 1996, pp.223 237.

10. Li, V.C. and Maalej, M. "Toughening in Cement Based Composites. Part II: Fiber Reinforced Cementitious Composites", Cement and Concrete Composites, Vol.18, No.4, 1996, pp.239 249.

11. Lin, W. L., "Toughness Behaviour of Fiber Reinforced Concrete", Proceeding of the Fourth International Symposium, RIIEM, Sheffield, UK, No.25, 1992, pp.299 - 315.

12. 박성현, 由口 방법을 중심으로 한 應用實驗計劃法, 英 志文化社, 1995, pp.93 131.

13. Bentur, A and Mindess, S., Fiber Reinforced Cementitious Composites, Eelsevier Applied Science Publishers, London and New York, 1990, pp.344 358.

14. Mindess, S., Young, J. F. and Darwin, D., Concrete, Prentice Hall, New Jersey, 2003, pp.95 96.

15. Neville, A. M, Properties of Concerete, Wiley, New York, 1996, pp.86 87.

16. Ghosh, S. N. and Yadav, S. N., Mineral Admixture in Cement and Concrete, ABI Books Private Limited, New Delhi, India, 1993, pp.226 265.

17. Banthia, N., "A Study of Some Factors Affecting the Fiber-Matrix Bond in Steel Fiber Reinforced Concrete", Canadian Journal of Civil Engineering, Vol.17, No.4, 1990, pp.610 620.

18. Katz, A. and Bentur, A., "High Performance Fibres in High Strength Cementitious Matrices", Proceedings of the International Workshop 'High Performance Fiber reinforced cement composites', RILEM, ACI, Stuttgart University and the University of Michigan, Mainz, Germany, 1991, No.18, 1992, pp.237 -247.

19. 원종필, 백철우, 박찬기, 한일영, 김방래, "구조용 합성 섬유의 형상 및 단면적 변화에 따른 부착 및 휨 성능", 콘크리트학회 논문집, 15권 5호, 2003. 10, pp.643 649.

\section{요 약}

본 연구에서는 마이크로 섬유인 탄소섬유와 매크로 섬유인 강섬유가 서로 하이브리드 형태로 결합되고 미세한 광물 혼화재인 실리카품이 치환된 고성능 하이브리드 섬유보강 콘크리트( $\mathrm{HPHFRC})$ 의 파괴계수(MOR), 횜인성 특성( $\mathrm{I}_{30}$ 과 $\mathrm{W}_{20}$ ), 유동성(슬럼 프)이 분산분석(ANOVA)을 통해 특성화 된다. $\mathrm{MOR}, \mathrm{I}_{30}$ (또는 $\mathrm{W}_{20}$ ), 슬럼프 데이터들은 휨 성능과 유동성을 평가하기 위한 특 성치로 사용된다. 특히, 실험회수를 줄이기 위하여 일부실시 직교배열에 따라 실험이 계획된다. 각 특성인자를 각 실험인자에 대해서 평가한 결과, 강섬유는 MOR 과 $\mathrm{I}_{30}$ 의 특성인자 측면에서 상당히 유의한 실험인자로 나타난다. 또한 분산분석 결과, 실 험인자의 유의도에 따라 다음과 같은 평가가 이용될 수 있다. 유동성(슬럼프) 감소는 실리카 흠, 강섬유, 탄소섬유 실험인자 순 서로 유의하게 나타난다. $\mathrm{MOR}$ 향상은 실리카품 $\fallingdotseq$ 탄소섬유), 강섬유 실험인자 순서로 유의한 것으로 나타난다. 횜인성 증진은 실리카품, 탄소섬유, 강섬유 실험인자 순서로 유의하게 나타난다. 실험범위 내에서 강섬유 $1.0 \%$, 탄소섬유 $0.25 \%$, 실리카품 5.0 $\%$ 의 조합이 각 특성치들을 가장 우수하게 향상시키고 유동성이 확보된 실험 조건으로 도출된다.

핵심용어 : 하이브리드 섬유보강 콘크리트, 매크로/마이크로 섬유, 유동성, 파괴계수, 휨인성 